\title{
EKSISTENSI KESENIAN MASYARAKAT TRANSMIGRAN DI KABUPATEN PRINGSEWU LAMPUNG STUDI KASUS KESENIAN KUDA KEPANG TURONGGO MUDO PUTRO WIJOYO
}

\author{
Oleh: Mutiara Dini Primastri \\ (Pembimbing Tugas Akhir: Dra. Budi Astuti M.Hum dan Indah Nuraini, S.S.T., M.Sn) \\ Jurusan Tari Fakultas Seni Pertunjukan, Institut Seni Indoonesia Yogyakarta \\ Alamat Email: mutiaradii@gmail.com
}

\begin{abstract}
RINGKASAN
Penelitian ini merupakan sebuah analisis deskriptif yang menggunakan pendekatan sosiologi dan antropologi untuk membedah tentang eksistensi kesenian masyarakat transmigran berupa kesenian kuda kepang di Kabupaten Pringsewu Lampung. Kesenian kuda kepang yang eksis di Kabupaten Pringsewu yaitu komunitas seni Turonggo Mudo Putro Wijoyo (TMPW).

Eksistensi adalah adanya sebuah keberadaan yang tidak hanya sebagai sesuatu yang "diam" akan tetapi menjadi sesuatu yang aktif dan memiliki peran di dalam lingkungannya. Melalui kajian sinkronik, kesenian kuda kepang TMPW tetap eksis saat ini karena memiliki fungsi sebagai seni pertunjukan yang menghibur (presentasi estetis), memuat nilai-nilai budaya, serta dapat menjadi identitas orang Jawa di Pringsewu. Kajian sinkronik didukung oleh kajian diakronik, yaitu kemunculan kesenian kuda kepang TMPW merupakan hasil dari rangkaian sejarah berupa eksistensi orang-orang yang bertransmigrasi di Pringsewu, melalui tahap eksistensi yaitu eksistensi estetis, etis dan religius.

Eksistensi kesenian kuda kepang TMPW tidak lepas dari faktor-faktor pendukungnya. Komunitas TMPW terus menunjukkan eksistensinya dengan melakukan inovasi pada segala aspekaspek penunjang koreografi dengan menjaga otentisitas agar tidak hilang dan menjadi ciri khas. Sebuah seni pertunjukan bersifat stimulus bagi masyarakat tentu mendapatkan respons, berupa respons positif dan respons negative.
\end{abstract}

Kata kunci: eksistensi, kuda kepang, transmigran. 
Mutiara Dini Primastri (EKSISTENSI KESENIAN MASYARAKAT TRANSMIGRAN DI KABUPATEN

\section{ABSTRACT}

This research is a descriptive analysis using sociology approach to analysed about art existence of transmigrant society, that is kuda kepang in Pringsewu Regency of Lampung. Kuda kepang that exist in Pringsewu is Turonggo Mudo Putro Wijoyo (TMPW) community.

Existence is the existence is not only as something "silent" but becomes something active and has a role in the environment. Synchronic studies, kuda kepang TMPW still exists because it has a function as an entertaining performing art (aesthetic presentation), contains cultural values, and can be a Javanese identity in Pringsewu. Synchronic studies are supported by diachronic studies, that is the emergence of kuda kepang TMPW is the result of a series of histories of the existence of people who transmigrated in Pringsewu, through the stage of existence of aesthetic, ethical and religious existence.

The existence of kuda kepang TMPW is not separated from the supporting factors. The TMPW community continues to show its existence by innovating on all aspects of choreography support and to be kept authenticity not lost and become characteristic. The performing arts have the character of stimulus for the society of course get the response, that is positive response and negative response.

\section{Keywords : existence, kuda kepang, transmigrant.}

\section{PENDAHULUAN}

Kuda kepang adalah kesenian kerakyatan yang populer di Pulau Jawa, dan dianggap peninggalan masa pra sejarah. Pada masa itu orang-orang masih mempercayai bahwa menghadirkan kekuatan roh binatang totem yaitu kuda dapat mengusir roh-roh jahat yang ada di lingkungan sekitar tempat tinggal mereka. Masyarakat Bali masih melestarikan seni pertunjukan dari masa pra-Hindu yaitu tari Sanghyang yang dipentaskan di pura bagian dalam yang disebut dengan jeroan (Soedarsono, 1998:10). Tari Sanghyang sama dengan seni kerakyatan kuda kepang yang ada di Pulau Jawa dan terdapat di berbagai daerah. Namun nilai-nilai ritual yang terkandung di dalamnya hampir tidak tampak jelas seperti di Bali karena pengaruh Islam yang begitu besar. Kesenian kuda kepang memiliki beberapa ciri khas yaitu, dipentaskan di tempat lapang, terbagi dalam beberapa babak pertunjukan, properti tari yang digunakan berupa pecut dan 
JOGED

ISSN: 1858-3989
Mutiara Dini Primastri (EKSISTENSI KESENIAN MASYARAKAT TRANSMIGRAN DI KABUPATEN PRINGSEWU LAMPUNG STUDI KASUS KESENIAN KUDA KEPANG TURONGGO MUDO PUTRO WIJOYO) kuda kepang, dan yang menjadi primadona adalah ada adegan intrance (ndadi) yang membuat pertunjukan kuda kepang menjadi menarik.

Kesenian kerakyatan ini sudah sangat populer di kalangan masyarakat desa maupun perkotaan. Kata "rakyat" merujuk pada sifat kesederhanaan dan tidak begitu rumit (Hadi, 2005:55) maka kesenian ini menjadi sebuah pertunjukan seni yang ringan, menghibur, dan mudah dikenal oleh masyarakat luas. Kesenian kuda kepang tidak hanya populer di Pulau Jawa saja, tetapi tersebar di seluruh daerah di Indonesia. Hal tersebut berkaitan dengan arus transmigrasi orang-orang Jawa ke berbagai daerah di luar Pulau Jawa. Pada tahun 1905 pemerintah Belanda melakukan migrasi orangorang Jawa untuk ditempatkan di daerah Way Semah, Gedong Tataan, Sukoharjo, Pringsewu hingga Wonosobo dan meningkat pesat sehingga setiap tahun terdapat 15.000 orangorang Jawa pindah ke Lampung (Sabaruddin, 2012:83). Kesenian kuda kepang di Kabupaten Pringsewu merupakan sebuah fenomena bersejarah karena kemunculannya di tanah perantauan juga melalui peristiwa bersejarah yaitu dampak dari arus transmigrasi.

Tidak ada gaya baru yang diciptakan oleh komunitas maupun Kabupaten Pringsewu sendiri yang akan menjadi hak milik Pringsewu, tetapi tetap melestarikan yang ada. Walaupun jika dibandingkan dengan kuda kepang yang berada di Jawa agak berbeda karena adanya sebuah proses perubahan dan perkembangan kebudayaan secara geografis yang diakibatkan adanya perpindahan manusianya yang disebut dengan difusi serta berlakunya inovasi yaitu aturan-aturan baru yang dibuat untuk menyesuaikan selera pasar (Sumaryono: 2011).

Tercatat ada 131 grup kesenian kuda kepang/kuda lumping di Kabupaten Pringsewu hingga tahun 2016 pada data rekapitulasi organisasi seni budaya. Salah satunya yaitu komunitas Turonggo Mudo Putro Wijoyo yang berada di Desa Pandansari, Kecamatan Sukoharjo, Kabupaten Pringsewu, Lampung. Adanya komunitas yang semakin banyak bermunculan menunjukkan bahwa semakin banyak orang yang tertarik dan terhibur, termasuk masyarakat pribumi sebagai masyarakat penonton yang ikut merespon kesenian tersebut dengan baik, seperti dalam buku Y. Sumandiyo Hadi yang berjudul Seni Pertunjukan dan Masyarakat Penonton memaparkan bahwa seni pertunjukan dan masyarakat penonton adalah sebagai suatu tindakan interaksionisme simbolik yang terletak pada pemahaman stimulus dan respon.

Suatu tradisi dikatakan hidup atau eksis oleh karena mampu disiasati dan beradaptasi dengan perubahan-perubahan sesuai dengan dinamika kehidupan sosial masyarakatnya (Sumaryono, 2011:22). Eksis atau eksistensi 
dalam Kamus Besar Bahasa Indonesia (KBBI) memiliki arti hal berada atau keberadaan yang tidak hanya ada, tetapi memiliki pengaruh terhadap lingkungannya. Sebuah tinjauan sosio-historis dengan kajian sinkronik dan diakronik dapat mengungkap keberadaan atau eksistensi kesenian kuda kepang di Kabupaten Pringsewu, Lampung.

Fenomena kesenian transmigran tersebut menjadi sebuah masalah yang menarik untuk diteliti. Mengingat bahwa keberadaan kesenian kuda kepang di tengah-tengah masyarakat yang bukan daerah asli kesenian ini lahir. Bahkan kesenian kuda kepang menjadi eksis dan berkembang di kalangan masyarakat Kabupaten Pringsewu. Oleh karena itu dapat ditarik rumusan masalah yaitu, bagaimana eksistensi kesenian masyarakat transmigran di Kabupaten Pringsewu Lampung dengan studi kasus kesenian kuda kepang Turonggo Mudo Putro Wijoyo.

Penelitian ini menggunakan pendekatan sosiologi. Ilmu sosiologi adalah ilmu yang membahas tentang gejala masyarakat, dan ilmu tersebut dapat mengupas sebuah keberadaan kesenian pada masyarakat penyangganya.

\section{PEMBAHASAN}

\section{A. Kesenian Masyarakat Transmigran}

Kesenian masyarakat transmigran adalah kesenian yang dibawa oleh penduduk transmigran asal Pulau Jawa di Kabupaten Pringsewu. Pada dasarnya transmigrasi adalah peristiwa perpindahan penduduk dari suatu daerah yang padat penduduk ke daerah yang jarang penduduknya. Transmigrasi tersebut dilakukan oleh pemerintah Belanda yang dilakukan secara besar-besaran.

Menurut Eko Sunu Sutrisno, masyarakat transmigran menghadirkan keseniannya di tempat tinggal barunya untuk mengobati rasa rindu dan menekan rasa sepi, selain itu memperkenalkan kesenian Jawa kepada penduduk pribumi (wawancara Eko Sunu Sutrisno tanggal 18 Agustus 2016). Muncullah ide untuk menghadirkan kesenian-kesenian asal daerah mereka ke tempat pemukiman baru yang mereka tempati. Fenomena munculnya kesenian masyarakat transmigran menjadikan bukti bahwa seseorang tidak bisa terlepas dari kebudayaan asalnya. Sejarah tentang masuknya kesenian masyarakat transmigran di daerah Pringsewu tidak begitu diketahui secara jelas dan tidak ada data-data maupun catatan yang dibuat mengenai masuknya kesenian transmigran ini, hanya diketahui bahwa masyarakat transmigran berpindah tempat ke Lampung membawa kesenian dari daerah asal mereka (wawancara Eko Sunu Sutrisno tanggal 18 Agustus 2016).

Pringsewu adalah daerah yang memiliki kondisi sosial yang unik, yaitu ditinggali oleh dua budaya yang berbeda namun keduanya 
Tabel 1. Data Organisasi Seni Dan Budaya

Kabupaten Pringsewu

\begin{tabular}{|c|c|c|c|}
\hline $\begin{array}{l}\mathbf{N} \\
\text { o. }\end{array}$ & Jenis Kesenian & $\begin{array}{l}\text { Jumlah } \\
\text { (Grup) }\end{array}$ & Keterangan \\
\hline 1 & Seni Tari Lampung & 24 & \multirow{11}{*}{$\begin{array}{c}\text { Data organisasi seni budaya } \\
\text { sampai dengan Desember } 2016\end{array}$} \\
\hline 2 & Orgen Tunggal & 104 & \\
\hline 3 & Musik Band & 10 & \\
\hline 4 & Campursari/Karawitan & 9 & \\
\hline 5 & Wayang Kulit & 13 & \\
\hline 6 & Ketoprak & 4 & \\
\hline 7 & Orkes Keroncong & 4 & \\
\hline 8 & Qasidah/Pengajian/Janeng & 35 & \\
\hline 9 & $\begin{array}{c}\text { Kuda Lumping/Kuda } \\
\text { Kepang/Ebeg/Reog }\end{array}$ & 131 & \\
\hline $\begin{array}{l}1 \\
\mathbf{0}\end{array}$ & Beladiri/Pencak Silat & 29 & \\
\hline & Jumlah & 363 & \\
\hline
\end{tabular}

berdiri sama-sama kuat, yaitu Jawa dan Lampung. Budaya Jawa di Pringsewu menjadi kuat karena mayoritas penduduknya adalah orang-orang suku Jawa, sedangkan budaya Lampung di Pringsewu juga menjadi kuat karena budaya Lampung adalah budaya asli pribumi.

Berikut ini adalah data rekapitulasi organisasi seni dan budaya Kabupaten Pringsewu Lampung.

Pada kolom 4 sampai 10 adalah kesenian pendatang (transmigran) dan bukan berasal dari kebudayaan Lampung itu sendiri.
Kesenian transmigran tersebut hidup cukup subur di wilayah Pringsewu. Terbukti jumlah organisasi yang tercatat termasuk dalam jumlah angka yang tidak sedikit, hal tersebut membuktikan bahwa keseniankesenian transmigran itu mampu bertahan dan bersaing di tengah-tengah kebudayaan Lampung.

Pada tabel di atas, terdapat 131 grup kesenian kuda kepang, sehingga menjadi jumlah grup kesenian terbanyak yang ada di Kabupaten Pringsewu. Gaya kesenian kuda kepang di Pringsewu terdapat 2 macam, yaitu 
gaya Jawa Timur-an yang disebut dengan pegon dan gaya Banyumas-an yang disebut dengan ebeg atau banyumasan. Kedua gaya tersebut memiliki ke khasan masing-masing.

Kesenian kuda kepang pegon bagian jogedan cenderung monoton, kostum yang digunakanpun sangat sederhana, namun mereka memiliki keunggulan pada saat adegan intrance, penari terlihat lebih agresif sehingga nampak lebih greget (wawancara dengan Wiwin Elawati tanggal 25 Maret 2017). Aksi penari yang mengalami intrance terlihat sangat "liar" dan menjadi terlihat lebih menarik. Penari melakukan gerak-gerak atraksi, seperti makan beling, berguling-guling dan bertindak semaunya untuk menunjukkan bahwa dirinya sedang mengalami intrance.

Kesenian kuda kepang gaya Banyumas-an justru sebaliknya, salah satunya yaitu komunitas seni kuda kepang Turonggo Mudo Putro Wijoyo. Komunitas ini merupakan komunitas yang eksis dibandingkan kesenian lainnya berdasarkan frekuensi pertunjukan, pengakuan masyarakat dan jumlah penonton. Pak Tugino adalah pemimpin komunitas tersebut dan di samping itu pekerjaan keseharian beliau adalah seorang juru kunci di makam Dusun Pandansari. Oleh karena itu beliau dipercaya sebagai pawang yang dapat berhubungan magis dengan makhluk-makhluk halus, seperti memasukkan roh dalam jiwa penari dan dapat menyembuhkan penari-penari yang mengalami intrance.

Penyajian kesenian kuda kepang TMPW dibagi dalam 3 babak. Babak pertama disebut dengan pembuka atau disebut dengan truntungan. Adegan ini menggambarkan permohonan izin penari untuk dapat menari di area pertunjukan tersebut. Hal itu terwujud dalam gerak sembahan oleh seluruh penari dengan 4 arah hadap yang dilakukan secara rampak simultan. Babak kedua atau bagian isi, dipecah lagi dalam 3 bagian, bagian pertama disebut kapatan yang menggambarkan kesiapan prajurit menghadapi peperangan. Bagian kedua disebut rowo kidul yang menceritakan tentang kisah seorang raja yang sedang jatuh cinta, yang dalam bahasa Jawa disebut dengan gandrung. Bagian ketiga disebut puspowarno (perangan) yang menggambarkan peperangan yang dilakukan oleh 2 orang laki-laki yang sama-sama kuat dan akan mengalami intrance. Babak penutup disebut dengan kapatan jantur yang merupakan bagian puncak dari pertunjukan kesenian kuda kepang yang dinanti-nanti oleh penonton yaitu terjadi adegan intrance oleh seluruh penari.

B. Eksistensi Kesenian Kuda Kepang Turonggo Mudo Putro Wijoyo

Kamus Besar Bahasa Indonesia mengartikan eksistensi sebagai sebuah kata yang berarti keberadaan. Eksis tidak hanya 


\section{JOGED}

ISSN: $1858-3989$
Mutiara Dini Primastri (EKSISTENSI KESENIAN MASYARAKAT TRANSMIGRAN DI KABUPATEN PRINGSEWU LAMPUNG STUDI KASUS KESENIAN KUDA KEPANG TURONGGO MUDO PUTRO WIJOYO) sebagai sesuatu yang ada dan hanya dilihat saja, tetapi berperan aktif sehingga memiliki daya guna terhadap kehidupan di sekitarnya. Benda-benda dapat bereksistensi apabila manusia bereksistensi, yaitu berbuat langsung terhadap objek yang diam. Pengertian tersebut mengungkap bahwa eksistensi menyangkut pengalaman langsung, bersikap aktif (Dagun, 1990:16-17).

Eksistensi kesenian kuda kepang Turonggo Mudo Putro Wijoyo dapat dianalisis dengan tinjauan sosio-historis sinkronik diakronik, karena kesenian merupakan suatu proses simbolis untuk memahami kausalitas historis yang menyangkut pertanggungjawaban akibat konkrit dari sebabsebab yang konkrit pula (Hadi, 2005:39).

\section{Sinkronik}

Kajian sinkronik adalah sebuah analisis yang menyangkut dengan peristiwa yang terjadi dalam suatu waktu yang terbatas, artinya adalah ketika kesenian itu hadir dalam masyarakat saat itu, ada dampak-dampak yang ditimbulkan dalam kurun waktu tertentu. Kesenian masyarakat transmigran dapat tetap menunjukkan eksistensinya manakala masih berfungsi dan dibutuhkan oleh masyarakat komunalnya (Sumaryono, 2011:135). Selain memiliki fungsi, kesenian kuda kepang TMPW juga menjadi sebuah identitas bagi masyarakat kaum transmigran, serta mengandung nilai-nilai budaya di dalamnya.

R.M. Soedarsono mengelompokkan seni pertunjukkan ke dalam 2 bagian besar yaitu fungsi primer dan fungsi sekunder (Soedarsono, 1998:57). Fungsi primer meliputi kesenian sebagai sarana ritual, sebagai hiburan pribadi, dan sebagai presentasi estetis. Fungsi primer ini merupakan fungsi kesenian yang kebanyakan lahir dari negara-negara berkembang yang mengacu pada daur hidup manusia serta mengacu pada peristiwa kesuburan (Soedarsono, 1998:57). Fungsi sekunder meliputi seni pertunjukan sebagai komoditi industri pariwisata.

Pada awal kemunculan kesenian kuda kepang di daerah asal, fungsinya adalah sebagai pertunjukan ritual, namun mengalami pergeseran fungsi yaitu menjadi pertunjukan sebagai presentasi estetis. Seni pertunjukan dari presentasi estetis menjadi sebuah hiburan yang dapat menimbulkan kesenangan bagi masyarakat penontonnya atau penciptanya sendiri, karena seni diciptakan sebagai kesenangan (Hadi, 2016:100). Selain itu, seni pertunjukan khususnya tari merupakan sebuah komunikasi, baik komunikasi yang terjalin antara penonton dengan maksud dari pencipta (koreografer), penonton dengan penonton, maupun sesama penari (pendukung). Fungsi komunikasi antar masyarakat lingkungannya 
tersebut juga dapat disebut sebagai perekat sosial.

Kesenian kuda kepang TMPW juga merupakan kesenian yang menjadi sebuah identitas masyarakat transmigran. Pada Kamus Besar Bahasa Indonesia, identitas memiliki arti ciri-ciri, keadaan khusus seseorang, dan jati diri. Inti dari ketiga uraian tersebut menjelaskan bahwa identitas adalah sesuatu yang bersifat milik pribadi yang dapat mewakilkan gambaran dirinya. Identitas selalu berhubungan dengan objek yang mengikutinya, pada pembahasan kali ini objek yang akan diteliti adalah kesenian kuda kepang Turonggo Mudo Putro Wijoyo. Keberadaan kesenian kuda kepang di Pringsewu memberikan pengetahuan tentang kehidupan masyarakat Jawa (transmigran) bagi masyarakat pribumi, yaitu orang-orang Jawa memiliki tradisi kejawen, yaitu terlihat pada pertunjukan kesenian kuda kepang TMPW terdapat sesaji yang kaya akan simbol seni yang bersifat ekspresif dan membutuhkan sentuhan penataan artistik (Hadi, 2005:87).

Pada penjelasan fungsi kesenian kuda kepang TMPW di atas telah dijelaskan bahwa kesenian tersebut merupakan sebagai media komunikasi antar penonton maupun seniman dengan penonton hingga menjadi perekat sosial diantara kedua hubungan tersebut. Perlu diketahui bahwa kesenian kuda kepang TMPW juga mengandung beberapa nilai penting yang berhubungan dengan kehidupan bermasyarakat dan muncul dari masyarakat penyangganya, diantaranya nilai universal, gotong royong, disiplin, ketekunan, sosial, dan estetik. Pada jurnal yang ditulis oleh Pratiwi Wulan Gustianingrum dan Idrus Affandi pada tahun 2016, nilai-nilai budaya tersebut merupakan nilai yang terkandung dalam budaya daerah itu sendiri (Pratiwi Wulan Gustianingrum dan Idrus Affandi, 2016:2733). Nilai universal diartikan bahwa kuda (ciri khas kesenian kuda kepang) menjadi simbol kekuatan, kejantanan, kewibawaan, dan kepahwalanan yang diketahui oleh seluruh manusia di mana pun dan diketahui sejak zaman dahulu hingga saat ini. Nilai gotong royong dapat dilihat dengan adanya sebuah bentuk kerjasama yang dibangun masyarakat untuk bersama-sama melestarikan kesenian kuda kepang TMPW. Nilai disiplin terwujud dalam pertunjukan kuda kepang yang tetap tertib meskipun terjadi kegaduhan akibat penari yang intrance, penonton telah bersikap disiplin, maka pertunjukan berlangsung aman dan lancar. Nilai ketekunan terlihat pada sikap penari yang rajin berlatih untuk dapat melakukan gerak tari. Nilai sosial jelas terlihat ketika pertunjukan berlangsung untuk dapat saling membantu demi tercapainya pertunjukan di tempat mereka. Nilai estetik terwujud pada aspek-aspek penunjang koreografi yang dibungkus dengan menarik. 
JOGED

ISSN: $1858-3989$
Mutiara Dini Primastri (EKSISTENSI KESENIAN MASYARAKAT TRANSMIGRAN DI KABUPATEN PRINGSEWU LAMPUNG STUDI KASUS KESENIAN KUDA KEPANG TURONGGO MUDO PUTRO WIJOYO)
Nilai-nilai tersebut merupakan nilai yang diserap dalam kehidupan sehari-hari.

\section{Diakronik}

Kajian diakronik adalah sebuah pendekatan yang bersifat historis. Kesenian kuda kepang adalah bentuk kesenian kerakyatan yang awalnya muncul pada masa pra sejarah ketika masyarakat masih menganut keyakinan animism dan dinamisme. Pada zaman dahulu orang-orang mempercayai bahwa roh binatang totem kuda dapat melindungi seluruh masyarakat desa. Keberadaan kesenian kuda kepang TMPW di daerah Pringsewu bukan sebuah kesenian yang tiba-tiba ada lalu eksis dikenal masyarakat, namun ada serangkaian cerita dibelakangnya, yaitu mengenai asal-usul keberadaan kesenian kuda kepang di Pringsewu.

Kesenian kuda kepang adalah seni pertunjukan yang populer di hampir seluruh desa di Pulau Jawa dan Bali, bahkan para transmigran dari Jawa di Sumatera, Kalimantan, Sulawesi juga banyak yang mengembangkan kesenian jenis ini (Sumaryono, 2011:142), termasuk di Kabupaten Pringsewu, Lampung. Kemunculan kesenian kuda kepang di Pringsewu adalah berkat eksistensi manusia (transmigran) itu sendiri. Menurut Kierkegaard dalam buku Filsafat Eksistensialisme yang ditulis oleh Save M. Dagun, eksistensi terikat dalam tiga tahap, yaitu estetis, etis, dan religius. Ketiga bentuk tersebut merupakan tindakan manusia dalam mengambil keputusan agar tetap bereksistensi di kehidupannya. Berikut penjelasan mengenai ketiga tahapan eksistensi menurut Kierkegaard.

\section{Eksistensi Estetis}

Kehidupan sehari-hari manusia selalu ditekan untuk terus mencapai target dengan kegiatan yang terjadwal dan dilakukan secara terus menerus. Mereka kurang melakukan penghiburan dalam diri sendiri. Eksistensi estetis menyangkut kesenian dan keindahan (Dagun, 1990:51) sangat diperlukan dalam kehidupan manusia karena dapat mendatangkan kesenangan dan penghiburan bagi keadaan batin setiap manusia. Ia bebas melakukan semua kehendak yang diinginkannya, termasuk memperoleh kenikmatan pengalaman emosi dan nafsu serta tidak ada batasnya dan kesenangan yang tidak terbatas pula (Dagun, 1990:51).

\section{Eksistensi Etis}

Eksistensi etis adalah sebuah pengendalian yang diperlukan bagi keseimbangan hidup manuisa, yaitu norma atau aturan yang sesuai dengan asas perilaku yang disepakati secara umum. Oleh karena itu perilaku manusia yang bersifat bebas dalam memenuhi hasrat duniawinya perlu dibatasi 
dengan norma-norma yang berlaku dalam masyarakat sehingga keadaan manusia tidak menjadi "liar".

\section{Eksistensi Religius}

Eksistensi religius merupakan tahap paling tinggi dan bergerak menuju kepada sesuatu yang absolut yaitu Tuhan (Dagun, 1990:52). Dua tahap eksistensi di atas dapat beralih ke tahap eksistensi religius dengan dijembatani oleh agama yang dianut manusia sesuai keyakinannya masing-masing.

Kesenian kuda kepang tergolong dalam ekistensi dalam tahap estetis yang dibatasi oleh eksistensi etis. Menurut Pujiyanto, dahulu saat awal pertama munculnya kesenian kuda kepang, masyarakat hanya sekedar memenuhi hasrat kenikmatan batinnya dengan mengadakan latihan tari kuda kepang oleh pemuda-pemudi desa yang diselenggarakan di balai desa (wawancara dengan Pujiyanto tanggal 16 Agustus 2016). Jika diperhatikan, orang-orang tersebut hanya menghabiskan waktunya secara sia-sia tanpa mendapatkan sesuatu apapun dan hanya mendapatkan kesenangan sesaat. Akan tetapi eksistensi estetis tetap harus dibatasi oleh eksistensi etis. Batasan itu dilakukan dengan membentuk sebuah komunitas dan membangun secara bersama-sama komunitas kesenian kuda kepang Turonggo Mudo Putro Wijoyo.
Pemuda-pemudi yang ikut di dalamnya menjadi lebih produktif dan dapat bertanggung jawab atas keleluasannya dalam menikmati sesuatu. Pemenuhan hasrat kenikmatannya telah melangkah ke tahap yang lebih baik yaitu mendapatkan pekerjaan di bidang yang mereka gemari hingga dapat mendatangkan penghasilan bagi orang-orang tersebut untuk mencukupi kebutuhan hidupnya walaupun penghasilan yang didapat tidak terlalu banyak dan cenderung pas-pasan. Keadaan tersebut dapat dianggap sebagai sebuah eksistensi, yaitu menyangkut keberadaan manusia yang ada tidak sebatas ada, tetapi menunjukkan aktifitasnya dalam lingkungan bermasyarakat, karena eksistensi tidak hanya menyangkut sebuah wujud atau keberadaan saja, tetapi juga mengenai proses dari kemungkinan menuju kenyataan (Dagun, 1990:50). Kesenian kuda kepang dapat mencapai tahap akhir yaitu eksistensi religius yaitu sebuah pencapaian kepada Tuhan. Melalui serangkaian peristiwa diadakannya pertunjukan kesenian kuda kepang tersebut tidak dapat dipungkiri adalah di mana sebuah proses manusia menuju kepada hal yang mutlak yaitu kepada Tuhan. Oleh karena itu kesenian kuda kepang yang melalui peristiwa sejarah adalah sebuah kesenian yang melalui tahap eksistensi estetis, etis dan religius. 
C. Faktor Pendukung Kesenian Kuda Kepang Turonggo Mudo Putro Wijoyo Tetap Eksis hingga saat ini

Kelompok kesenian ini lebih mengedepankan inovasi dari segala aspekaspek penunjang koreografi, maka terkesan selalu baru, tidak terlalu monoton serta dapat dinikmati unsur keindahannya. Faktor-faktor pendukung yang menyebabkan komunitas ini masih eksis hingga saat ini, yaitu dari segi manajemen organisasi, bentuk penyajian maupun aspek-aspek penunjang koreografi. Faktor-faktor pendukung tersebut perlu dibahas untuk lebih mempertajam isi kesenian kuda kepang TMPW sehingga dapat menarik bagi masyarakat.

\section{Manajemen Organisasi}

Komunitas ini dikelola dengan baik oleh organisasi di dalamnya, terlihat pada struktur organisasi pada komunitas ini jelas dan menjalankan tugas sesuai job descriptionnya, sehingga segala pekerjaan-pekerjaan yang menyangkut keperluan untuk kepentingan kemajuan organisasi, terlaksana dengan baik oleh para pengurus organisasi. Misalnya bendahara hanya mengatur keluar masuk dana organisasi, tidak ikut campur dalam bidang humas, sehingga tidak terjadi kekeliruan pada penyampaian info. Oleh karena itu manajemen dalam sebuah seni pertunjukan harus berjalan maksimal agar dapat mendukung pertunjukan yang akan dipentaskan. Manajemen akan membantu organisasi seni pertunjukan untuk dapat mencapai tujuan dengan efektif dan efisien (Permas, 2003:19).

\section{Bentuk Penyajian}

Bentuk penyajian adalah wujud dari seluruh pertunjukan yang dipentaskan pada saat itu. Seni pertunjukan termasuk kesenian kuda kepang TMPW senantiasa dipahami dalam pengertian teks dalam konteks, artinya bahwa setiap kehadiran bentuk seni pertunjukan (surface structure) senantiasa implisit membawa serta konteks isinya (deep structure) (Hadi, 2016:6). Bentuk keseluruhan pertunjukan kesenian kuda kepang Turonggo Mudo Putro Wijoyo tidak hanya menyangkut masalah bentuknya saja, namun mengandung isi yang ingin disampaikan penciptanya kepada penonton. Ada makna-makna yang terkandung yang tertuang dalam setiap babak pertunjukannya.

\section{Aspek-Aspek Penunjang Koreografi}

Kesenian kuda kepang sebagai kesenian masyarakat transmigran di Pringsewu mengalami perkembangan dan perubahan kebudayaan yang disebut dengan proses difusi (diffusion). Oleh karena itu beberapa bentuk aspek-aspek penunjangnya mengalami perubahan dari bentuk aslinya dari daerah asalnya, namun tetap menjunjung tinggi keorisinalitas dan pakem yang digunakan oleh kesenian kuda kepang. Berikut adalah penjelasan mengenai stimulus yang dilakukan 
oleh komunitas kesenian kuda kepang TMPW dan telah mengalami proses difusi.

Gerak adalah dasar ekspresi dari semua pengalaman emosional yang dibentuk menjadi pola-pola gerak dinamis dan kontinyu (Hadi, 2012:10-11). Gerak-gerak yang dilakukan para penari TMPW lebih variatif, yaitu lebih banyak motif geraknya seperti tayungan, muryani busana, dolanan sampur dan trisik yang tidak terdapat di komunitas kesenian kuda kepang lainnya.

Kesenian kuda kepang TMPW adalah jenis kuda kepang gaya banyumasan yang memiliki ciri khas tersendiri yaitu iringannya berupa gending ricik-ricik dan eling-eling krido. Hal tersebut menjadi keunggulan kesenian kuda kepang TMPW dan menjadi daya tarik bagi masyarakat penontonnya. Ada bentuk kesenian kuda kepang lainnya yang hanya menggunakan alat musik gamelan berupa kenong, kendang dan gong. Bentuk iringan tersebut berbeda jauh dengan bentuk iringan kesenian kuda kepang yang sudah memiliki iringan ciri khas.

Aspek penunjang koreografi berupa rias dan busana juga dapat menambah estetika kesenian kuda kepang. Eyeshadow dan blush on pada rias wajah yang digunakan adalah warna-warna yang mencolok seperti pink dan hijau, sebenarnya jika melihat rias wajah seperti itu terlihat menor atau berlebihan, tetapi menurut Sri sebagai penata rias, dengan rias wajah yang seperti itu dapat menjadi ciri khas tersendiri sebagai seni kerakyatan (wawancara dengan Sri tanggal 31 Maret 2017). Kostum yang digunakan dari satu tempat pertunjukan satu dengan tempat pertunjukan lainnya menggunakan kostum yang berbeda. Selain ada banyak variasi, terdapat inovasi berupa tambahan aksesoris berupa tapis Lampung yang dijadikan gelang penari. Keadaan tersebut menunjukkan adanya inovasi atau pembaharuan yang disesuaikan dengan "tempat tinggal" kesenian itu sekarang. Hal tersebut menjadi nilai estetik kesenian kuda kepang TMPW bertambah dan menjadi daya tarik penonton.

Penari merupakan "alat" ekspresi menggunakan tubuhnya sendiri dengan menghasilkan gerak. Gerak-gerak yang dilakukan oleh penari adalah hasil proses pencarian dan penjelajahan dalam menciptakan sebuah ekspresi atas dasar rencana pencipta tari (Hadi, 2012:113). Pada kesenian kuda kepang, para penari dianggap berhasil mewujudkan konsep penata tari yang memiliki keinginan menciptakan tarian yang indah.

Di dalam komunitas kesenian kuda kepang TMPW terdapat seorang penari yang memiliki teknik dan penguasaan komposisi tari yang lebih baik dibanding dengan penari lainnya. Penari tersebut bernama Rizky, seorang berjenis kelamin laki-laki berusia 20 
JOGED

ISSN: 1858-3989
Mutiara Dini Primastri (EKSISTENSI KESENIAN MASYARAKAT TRANSMIGRAN DI KABUPATEN PRINGSEWU LAMPUNG STUDI KASUS KESENIAN KUDA KEPANG TURONGGO MUDO PUTRO WIJOYO) tahun. Rizky merupakan penari yang dianggap sudah mencapai ketiga konsep pedoman tari Jawa yaitu wiraga, wirama, wirasa, dibandingkan dengan penari lainnya. Seorang penonton bernama Catur Kurniasih mengatakan, jika Rizky belum keluar untuk menari, berarti belum sah dalam menonton pertunjukan kesenian kuda kepang tersebut (wawancara dengan Catur Kurniasih tanggal 31 Maret 2017).

4. Peran Pemerintah

Kabupaten Pringsewu adalah kabupaten yang masih sangat baru namun telah menunjukkan kemajuannya di berbagai bidang, salah satunya bidang seni dan budaya. Pemerintah Kabupaten Pringsewu menaruh perhatian lebih kepada bidang seni budaya yaitu dengan melakukan berbagai kegiatan seperti lomba-lomba, festival, pembinaan maupun pendanaan terhadap kelangsungan hidup kesenian tersebut. Walaupun kesenian yang ada di Pringsewu merupakan kesenian yang muncul dari dua kebudayaan yang sangat kuat di Pringsewu yaitu Jawa dan Lampung (pendatang dan pribumi), akan tetapi pemerintah setempat memberlakukan adil atas kehidupan kesenian tersebut. Keduanya samasama dibina dengan sebaik-baiknya, maka kehidupan antar kedua budaya tersebut tetap harmonis walaupun hidup dalam satu lingkungan masyarakat.

\section{III.PENUTUP}

Kesenian kuda kepang adalah salah satu dampak dan bukti adanya peristiwa transmigrasi secara besar-besaran yang dilakukan pemerintah Belanda pada tahun 1905 ke Lampung. Kesenian kuda kepang merupakan kesenian yang eksis di antara kesenian lainnya yang ada di Kabupaten Pringsewu. Hal tersebut terbukti dengan adanya data rekapitulasi seni budaya hingga tahun 2016 Kabupaten Pringsewu yang menunjukkan bahwa kesenian kuda kepang memiliki jumlah komunitas yang paling banyak yaitu 131 grup. Kesenian kuda kepang di Kabupaten Pringsewu dibawa oleh masyarakat transmigran bukan lagi sebagai sebuah ritual, tetapi sebuah seni pertunjukan sebagai presentasi estetis. Salah satu bentuk kesenian kuda kepang banyumasan/ebeg yang eksis di Kabupaten Pringsewu adalah kesenian kuda kepang Turonggo Mudo Putro Wijoyo.

Pada KBBI, eksis atau eksistensi memiliki arti sebuah keberadaan. Keberadaan sesuatu tersebut tidak hanya sebagai sesuatu yang "diam" akan tetapi menjadi sesuatu yang aktif dan memiliki peran di dalam lingkungannya. Sebuah keberadaan kesenian kuda kepang TMPW dapat dikaji melalui pendekatan sosio-historis berupa kajian sinkronik dan diakronik. Kajian sinkronik adalah sebuah pendekatan yang melihat dari peristiwa saat ini saja, yaitu fungsi dalam 
kehidupan bermasyarakat yaitu sebagai seni pertunjukan yang menghibur dan sebagai media komunikasi antar penonton, selain itu menjadi identitas bagi masyarakat suku Jawa di Pringsewu serta mengandung nilai-nilai budaya. Kajian sinkronik didukung oleh kajian diakronik, yaitu berasal dari suatu rangkaian peristiwa panjang, yaitu sebagai hasil dari eksistensi orang-orang yang bertransmigrasi di Pringsewu, menurut Kierkegaard, eksistensi manusia tersebut dibagi menjadi tahap 3 yaitu eksistensi estetis, etis dan religius.

Eksistensi kesenian kuda kepang TMPW tidak lepas dari faktor-faktor pendukungnya yaitu menejemen organisasi yang baik, bentuk penyajian yang urut dan tersusun, peran pemerintah serta dengan melakukan beberapa inovasi pada segala aspek-aspek penunjang koreografi yang meliputi gerak, rias dan busana, iringan dan penari, akan tetapi bentuk keutuhan asli atau pakem tetap dijaga agar tidak hilang dan menjadi ciri khas.

\section{DAFTAR SUMBER ACUAN}

A. Sumber Tercetak

Dagun, Save M. 1990. Filsafat Eksistensialisme. Rineka Cipta. Jakarta.

Hadi, Y. Sumandiyo. 2005. Sosiologi Tari. Pustaka. Yogyakarta.

Cetakan II 2012. Koreografi Bentuk-Teknik-Isi.Cipta

Media.Yogyakarta.
Cetakan II 2016. Seni Pertunjukan Dan Masyarakat Penonton. Cipta Media. Yogyakarta.

Permas, Achsan, dkk. 2003. Manajemen Seni Pertunjukan. PPM. Jakarta.

Pratiwi Wulan Gustianingrum dan Idrus Affandi. 2016. "Memaknai Nilai Kesenian Kuda Renggong Dalam Upaya Melestarikan Budaya Daerah di Kabupaten Sumedang". Journal Of Urban Society's Art.Volume 3 Nomor 1.

Rekapitulasi Organisasi Seni Dan Budaya Tahun 2015 oleh Kepala Bidang Kebudayaan Dinas Pendidikan Kebudayaan Dan Pariwisata Kabupaten Pringsewu Lampung.

Sa, Sabaruddin. 2012. Sai Bumi Ruwa Jurai Lampung Pepadun dan Sai Batin. Buletin Way Lima Manjau. Jakarta.

Soedarsono, R.M. 1998. Seni Pertunjukan di Era Globalisasi. Direktorat Jendral Pendidikan Tinggi Departemen Pendidikan dan Kebudayaan. Jakarta.

Sumaryono. 2011. Antropologi Tari Dalam Perspektif Indonesia. Badan Penerbit ISI Yogyakarta. Yogyakarta.

B. Nara Sumber

Eko Sunu Sutrisno, 55 tahun, kepala bidang pelayanan masyarakat Museum.

Wiwin Elawati, 33 tahun, perias tari.

Pujiyanto, 46 tahun, pelaku aktif kesenian kuda kepang Krida Budaya.

Catur Kurniasih, 37 tahun, guru. 